\title{
A Review On The Biology And Symptoms Of Attack Of Mango Red Banded Catterpillar (Autocharis Albizonalis Hampson)
}

\author{
Mainak Bhattacharyya \\ Designation: Teacher of Itta High School, West Bengal, India \\ Former Researcher Bidhan Chandra Krishi Viswavidyalaya, Mohanpur, Nadia, West Bengal
}

\begin{abstract}
Several insect and non insect pests attack the mango at several stages of bearing. Red banded caterpillar or Autocharis albizonalis Hampson was the minor pest of mango but very recently emerged as a serious pest all over the world. The larval instars were the most destructive stage of this pest. They were characterised by the red and white alternate bands on the body. Pupation occurred in the dry twigs of the braches or in soil inside a brownish cocoon. This pest attacked the mango fruit from the pea sized till the maturity of the fruit causing boring of the fruits through several tunnels by the larvae. The matured instar larvae reached the seed yet to harden and tunnelled them, excreted inside and exposed the fruits to the secondary infestation by micropathogens. The review paper presents all the work that had been done till date about the life cycle and symptoms of attack of the concerned pest
\end{abstract}

Keywords: larval instar, life cycle mango, micropathogens, red banded caterpillar

\section{Introduction}

Many insects and non insect pests like mite attack mango. The number exceeds more than 400 in the world according to Tandon and Vergese, 1985. Nearly 260 insect and mite pest have been reported from Indian subcontinent out of which Kapadia 2003, identified 30 pests to be mainly serious , capable of causing losses to the crop yield and growth. Reports made by various scientists (Tandon and Srivastava, 1982, Tandon and Lal, 1977 ; Fletcher , 1917; Wadhi and Batra , 1969 and Peva and Mohyuddin, 1977) enlisted 260 species of insects as major and minor pests of mango in Pakisthan among them 127 are foliage feeders ;87 are fruit feeders ;36 feed the inflorescence; 33 inhibits the buds and 25 feed on branch and trunk.

According To Srivastava( 1998), hoppers, stem borers, shoot borers, fruit flies, stone weevil, leaf miners, termites, scale insects, thrips, aphids and ants were major pests of mango. Several fruit borer species of mango is identified so far in different mango orchards .Sengupta \& Behura (1995) reported Noorda albizonalis Hampson ,Ctenomeristis ebriola Meyrick, Dichocrosis punctiferalis Guence.

Bhumannavar and Jacov (1990) recorded a new fruit borer of mango, Tirathabamundella for the first time in the Andaman and Nicobar islands showed the record of red banded caterpillar (Deanolis sublimbalis, synonyms are Dianolis albizonalis ,Noorda albizonalis, Autocharis albizonalis) Jha and Sarkar (1991)reported this pest from Malda during a thorough and acute survey in the mango orchards of Malda and Murshidabad districts of West Bengal, India. This pest is thought to have been recorded as a new pest, causing alarming losses of mango in Andhra Pradesh, India.

\section{Incidence of Mango fruit borer}

the scarcity of literature about the mango red banded caterpillar suggested that this pest was a minor pest and gained a status of a major pest very recently. Surveys in the Philippines and Papua New Guinea have found infestation rates of 40-55\% ( Tipon 1979 in Golez 1991, Pinese 2005). The Host range of the borer is found to be Mango (Mangifera indica, Family: Anacardiaceae);Kuini ( Mangifera odorata) in Papua New Guinea and Indonesia;Mangifera minor a wild fibrous mango found in Papua New Guinea; and Boueaburmanica in Thailand ( Kalshoven 1981, Waterhouse 1998, Krull 2004, Tenakanaiet al . 2006). Sahoo and Jha (2009) reported that fruit borer, Autocharis albizonalis Hampson, is a predominant pest of mango has recently emerged as a serious pest. The damage due to this pest showed $10 \%-52 \%$ damage from pin head stage to full maturity in Malda and Murshidabad, Nadia and Hooghly districts of West Bengal, India.

According to Sujatha and Zeheruddin (2002) the pest has a short life cycle of less than one month with 3 to 4 generations during the fruiting season. Fecundity ranged from 4 to 38 with pre-ovipositional period of 2 days. The larvae passed through 3 larval instars within 12.4 days and they pupate in the dead wood, cracks and crevices of the bark for a period of 13 to 43 days after pre-pupal period of 2 to 7 days. They also noted the pest has got pre pupal diapauses during off season . 
According to Sahoo and Das (2004), April-May was the congenial period for the fruit borer infestation when the fruits were medium in size. The crop loss was $4 \%$ to $42 \%$ at this stage. The loss of full grown fruits was found at this stage and is $25 \%-42 \%$. While it was only $3 \%$ in marble sized fruits. Sahoo and Jha (2009), showed that the maximum percentage of damaged fruit $(32.23 \pm 0.49)$ by this borer found during early part of the second fortnight of April. Damage is drastically reduced afterwards as the mature larvae pupated. At the second fortnight of April population of mango fruit borer again increased. The percentage of fruit damaged in the early part of the second fortnight of May had been found to be $22.69 \pm 0.34$.

Sahoo and Das (2004) stated that two clear broods were found during the fruiting season. The $1^{\text {st }}$ attack by the larvae appeared in the second to third week of March when fruits were in the marble stage (about $1 \mathrm{~cm}$ in diameter) mainly after the $1^{\text {st }}$ pre-monsoon shower. In West Bengal preferably during " Kalbaishakhi " months in West Bengal, India. The second generations appeared during $4^{\text {th }}$ week of April to $1^{\text {st }}$ week of May when the fruits were in medium to full grown size, but the kernels were yet to harden. The full grown larvae pupated on trashes, on the soil or in the cracks and crevices. In 1991 Golez reported that peak infestation of this borer was found in summer months of March - April. The important factor for the appearance of this borer was the availability of the fruit. In the absence of fruits the adults failed to reproduce. Rather they might also have been seen to survive in the fruits like cashew, avocado, chico, guava, jackfruit, papaya and star apple as it's alternate host.

\section{Biology of the Pest}

Behura and Sengupta (1955) reported the fruit borer (Noorda albizonalis infestation) in Puri district of Orissa, India. They had reported that female moth laid milky white oval eggs in masses near the distal end of the fruit or fruit apex. The incubation period was reported to be 2-3 days and pre-oviposition period was 1.5-2.5 days. Hatching occurred after 3 days and newly hatched larvae bored through the tender fruits at the early stage via distal end of the fruit. Fully matured larval instar pupated preferably inside the fruits or outside in the soil or cracks, crevices or sometimes in the branch.

\section{III.1.Larvae}

The larva of Autocharis albizonalis Hampson completed 5 larval instars and underwent pupation thereafter either inside the fruits or in the soil or preferably in dry branches. Krull and Basedow( 2006), reported that the fruit borer entered the fruit through one bore hole made typically on the lower half of the fruit. According to Golez 1991, Waterhouse 1998, two larval instars fed on the mango flesh, while the later instars fed on the seed. One fruit sometimes seen to have as many as 11 larvae although there is often only one ( Leefmans \&Vecht 1930, Waterhouse 1998). If competition occured between larvae in the same fruit, some individuals were seen to leave that fruit to search for others.Golez 1991 depicted that larvae moved between fruits by the use of " silk threads". The larva is quite distinctive in appearance with alternating white and red bands and a black collar on the first segment. The head is brown or black. According to Fenner 1997 the caterpillar grew to about $2 \mathrm{~cm}$ in length.

\section{III.1.1The $1^{\text {st }}$ instar larvae}

Cylindrical, brownish , 4-9 $\mathrm{mm} \mathrm{L \times 1.08} \mathrm{mm} \mathrm{W}$. Development period was 2 days. Sengupta and Behura (1955) described that the full grown caterpillars were about $2.5 \mathrm{~cm}$ in length and dorsum being red with white intersegmental streaks and dorsoventral regions were slightly hairy.

\section{III.1.2The $2^{\text {nd }}$ instar larvae}

Brownish-yellow : $10 \mathrm{~mm} \mathrm{~L} \times 2.0 \mathrm{~mm}$ W. Development period was 2-3 days according to Sahoo and Jha (2009)

\section{III.1.3The $3^{\text {rd }}$ instar larvae}

Brown head, white body and red intersegmental band $(12.3 \mathrm{~mm} \mathrm{~L} \times 2.2 \mathrm{~mm} \mathrm{~W})$. Development period was 3 days according to Sahoo and Jha (2009).

\section{III.1.4The $4^{\text {th }}$ instar larvae}

Morphologically similar to $3^{\text {rd }}$ instar period 2-3 days according to Sahoo and Jha (2009).

\section{III.1.5The $5^{\text {th }}$ instar larvae}

Head dark brown, mandibles heavily sclerotized and black with 3 pairs of thoracic legs and 5 pairs of abdominal legs . Size varied from $19.5 \mathrm{~mm} \times 3.5 \mathrm{~mm}$; Period of development was 2 days according to Sahoo and Jha( 2009).

\section{III.2.Prepupal stage}


Slightly green colouration was found intersegmentally between red bands. The prepupal duration was 4.506 days according to Sahoo and Jha( 2009).Location of pupation was in the dry branches of mango plants. During prepupal stage the larvae showed minimal mobility, becomes sluggish ( Tenakanai et al 2006). Prepupae turned a blue to green colour on the white bands ( Krull 2004).

\section{III.3.Pupal stage}

According to Sujatha and Zeheruddin (2002) the pest had life cycle of less than one month with 3 to 4 generations during fruiting season. Fecundity ranged from 4-38 with a pre-ovipositional period of 2 days . Pupa was dark brown $10 \mathrm{~mm}-16 \mathrm{~mm} \times 2.5 \mathrm{~mm}-3 \mathrm{~mm}$. Compound eye antennae and legs were variable and tip portion of the pupal stage slightly pointed. The larva pupated in the dead and dry wood, cracks and crevices of the bark or in the soil sometimes it could also be noticed that the pest had got prepupal diapauses during off season. According to Leefmans\& Van der Vecht 1930 the pupa spun around itself soil or bark particles and is $11 \mathrm{~mm}-12$ $\mathrm{mm}$ long. Pupae are pale brown and gradually turn dark brown as they mature ( Tenakanai et al 2006).

\section{III.4.Adults}

In 1993, Butani described that adults were small brown moths with wing span of $20 \mathrm{~mm}-24 \mathrm{~mm}$. According to Golez 1991, the body of the male moth was tubular blunt with black brown hair. Had blackish brown compound eyes . Antennae brownish $6 \mathrm{~mm}-9 \mathrm{~mm}$. Head with prominent brown snout. Thorax brown and forewings ashy wood in colour .Mesothoracic legs yellowish in colour and tarsus 6 segmented with presented with presence of brush like dark brown hairs on lower side of the tibia tarsus of male only. The size of the female was smaller than male, $10 \mathrm{~mm}-13 \mathrm{~mm}$ long and wing span of $21 \mathrm{~mm}$. Body tubular with pointed abdomen straight yellow -brown hairs and mesothoracic legs without hairs. It had been observed by certain workers that moth emergence occurred during 8:00-8:40 pm.

Adult emergence occurred after 12-15 days of pupation. The time of emergence was nearly at 8:008:15 pm(Mainak Bhattacharyya, 2010). Golez (1991) reported that adults were generally nocturnal, spent most of their time resting under the leaves on the host tree during the day. Furthermore he noticed that the fecund females preferred to oviposit on fruit protected from full light, which implied that some egg laying activity occurred during the daytime. Pheromone gland extracts from 24-72 hour old actively calling females , at 2-3 hours into the scotophase was taken by Gibb et al. (2007) which inferred that mating took place within 1-3 days from emergence and females called at night.Sujatha and Zeheruddin (2002) found out that the adult moths were sluggish and were not active fliers which indicated the reason why the pest attack or adult migration and spread to other mango growing regions was not found.Fenner (1997) described the adult moths to have wings of a shinning bluish-fawn colour with a well marked darker border and a narrow, dark streak across the end of the forewing cell. The length of the forewing was about $13 \mathrm{~mm}$. Gibb et al . (2006) also stated that the males can be identified by an abdomen that extended beyond the hind wings.

\section{III.5.Eggs}

Krull \&Basedow (2006) found that oviposition occurred at the base of the peduncle covered with the dried leaves in $70 \%$ of the cases. They also said that eggs are usually laid in groups of two, though single egg laying and egg masses contained upto 14 eggs are recorded. According to Golez(1991) oviposition occurred as early as 45 days after the setting of fruit and continued upto the fruit maturity. He also described that the eggs were oval, waxy white and were laid in masses on the fruit apex and hatched after 3-4 days. The insects passed through 5 larval instars with total development period of 14-20 days. The prepupal and pupal period lasted for 2 to 3 days and 9 to 14 days respectively.Longevity of the adult was described from 8 to 9 days and life cycle completed with 28 to 41 days.

\section{Key symptoms of attack}

Red banded mango caterpillar fed on the mango fruit in all stages of fruit development. First and Second instar caterpillars fed just beneath the skin surface, tunnelling towards the seed. Later instar larvae fed on the inner content of the fruit i.e the seed. Secondary pests infestation by bacteria and fungi were seen afterwards causing fruit rotting and the fruits fell from the tree prematurely ( Kalshoven 1981, Waterhouse 1998). In Papua New Guinea all sized fruits are preferably attacked by the borer but marble sized fruits were the preferred sites for oviposition and therefore frequently infested.(Krull 2004)

\section{1Stage 1 of attack}

In West Bengal the red banded caterpillar attacked the mango fruits at two stages . Caterpillar from hatched eggs bored into the tissues and made tunnel towards the seed. This produced the typical small hole at the distal end of the fruit. The hole enlarged and faecal matter accumulated. The fruit thus collapsed . Infested fruits become unfit for human consumption. Firstly the pest attacked at marble stage of fruits. The second stage 
of infestation occurred during the egg size of the fruit ( Anon 2007). The Study of Sahoo and Jha (2009) confirmed this observation.

Golez (1991), said that infestation of fruit borer occurred as early as 45 to 55 days after flower induction and continued up to fruit maturity. Greater percentage of damage was however observed in the medium sized fruit, 75 to 85 days after flower induction.

\section{IV.2.Stage 2 of attack}

Secondary microbial infection caused necrosis. The seed was preferred as food source by the larvae. Early instars penetrated small fruits. Later instars preferred larger fruits. Sometimes due to heavy infestation the cracking of fruits and fruit dropping occurred in artificially inoculated fields larvae reached the site of entry hole into the fruits in 507 minutes.

Sahoo and Jha (2009) reported that seed was preferred food of the larvae as compared to the pulp in the laboratory as well as in the field condition and early instar larvae generally preferred small size of fruit but later instars preferred large sized fruits.

\section{Conclusion}

Mango fruit borer, preferably known as the red banded caterpillar Autocharis albizonalis Hampson, though was a minor pest gradually gaining importance. Mango fruits were found to be attacked by this borer during the pea stage to the maturity stage of the fruit. Thereafter fruit rotting and necrosis of the fruit occurred due to secondary microbial infestation. Even very low numbers of this pest would be highly problematic for commercial mango producers.

\section{Acknowledgement}

I would like to thank Prof ShantanuJha, Department of Entomology, Bidhan Chandra KrishiViswavidyalaya, Mohanpur, Nadia. I also want to convey by deepest sense of gratitude to Nairita Bhattacharyya, my Maa, Papa and my friend Paromita Bhowmik.

\section{References}

[1]. Anonymous (2007), Surveillance of different mango pests and their natural enemies during 2003-2004 and 2004-2005. In: Ann , Report All India Coordinated Research Project on Sub Tropical Fruits, B.C.K.V. Mohanpur centre.

[2]. Asati, B.S.; Sarnaik , D.A. ; Thakur , B.S.; Rai , N.(2004). Correlation studies in round fruited brinjal against fruit borer ( Leucinodes orbonalisGuen). Progressive- Horticulture 36(1): 132-134.

[3]. Banerjee, M.K.;Kalloo (1989). Role of phenols in resistance to tomato leaf curl virus, fusarium wilt and fruit borer in Lycopersicon Current- Science. 58(10):575-576

[4]. Bhumannavar BS, Jacob TK (1989) Psoraleococcus nr. multipori (Morrison) on mango on an Andaman island. FAO Plant Protection Bulletin 37, 134.

[5]. Bhumannavar, BS (1991a) Record of Citripestis eutraphera (Meyrick) (Pyralidae: Lepidoptera) on Mangifera andamanica in India. Journal of the Bombay Natural History Society 88, 299.

[6]. Butani , D.K. (1979). Insect and Fruits .Pub : Periodical Expert Book Agency, New Delhi . 415pp.

[7]. Butani, D.K (1993). Mango pest problem .Pub : Periodical Expert Book Agency, New Delhi . 415pp.

[8]. Gibb AR, Pinese B, Tenakanai D, Kawi AP, Bunn B, Ramankutty P, Suckling DM (2007) 9Z -11-Hexadecenal and (3Z,6Z,9Z)Tricosatriene: sex pheromone components of the red banded mango caterpillar Deanolis sublimbalis. Journal of Chemical Ecology $33,579-589$.

[9]. Golez, H.G.(1991). Bionomics and control of mango seed borer Noorda albizonalis Hampson ( Pyralidae: Lepidoptera). Acta Horticulture, 291: 418-424.

[10]. Jha , S. and Sarkar, A.(1991). Mango in Malda, Bidhan Chandra KrishiViswavidyalaya, Mohanpur,Nadia ., W.B.:13 p

[11]. Krull SME (2004) Studies on the mango-ecosystem in Papua New Guinea with special reference to the ecology of Deanolis sublimbalisSnellen (Lepidoptera, Pyralidae) and to the biological control of Ceroplastesrubens (Homoptera, Coccidae). PhD. Thesis, Institut fur Phytopathologie und AngewandteZoologie der Justus-Liebig-Universitat Gießen, Versuchsstation, Alter SteinbacherWeg 44, Gießen.

[12]. Biological Notes On DasynusManihotisblote by $\mathrm{Dr} S$.Leefmans With PlateXII. Available online at :http://dare.uva.nl/cgi/arno/show.cgi? fid=149815( Accessed June 2014)

[13]. Leefmans(S.) \& Van Der Vecht(J.) . De rood-geringde manga-rups.( The red-ringed Mango Caterpillar.)- KorteMeded. Inst. Plziekt., no .14,6pp.,2pls.Buitenzorg, 1930.

[14]. Mohyuddin AI, Mahmood R (1993) Integrated control of mango pests in Pakistan. ActaHorticulturae341, $467-483$.

[15]. Moore D (2004) Biological control of Rastrococcus invadens. Biocontrol News and Information 25, $17-27$.

[16]. Moore, S. and W.H. Stein (1948). In: Methods Enzymol.(eds. Colowick, S.P . and Kaplan, N.D.), Academic press, New York , $3: 468$.

[17]. Sahoo , A,K , and Das, B.K.(2004) incidence and biological observations of mango fruit borer, Deanolis albizonalis Hampson( Pyralidae: Lepidoptera) in West Bengal. Environmental and Ecology ,22(Spl,2); 180-183.

[18]. Sengupta GC, Behura BK (1955) Some new records of crop pests from India. Indian Journal of Entomology 17, $283-285$.

[19]. Sengupta GC, Behura BK (1957) Annotated list of crop pests in the state of Orissa. Memoirs of the Entomological Society of India $5,1-44$.

[20]. Tandon, P.L and Lai, B.(1977). Predatory spider associated with insects pests of mango. Bulletin Entomology, 24(2):144-147.

[21]. Tandon PL (1998) Management of insect pests in tropical fruit crops. In 'Tropical fruits in Asia: diversity, maintenance, conservation and use. Proceedings of the IPGRI-ICAR-UFTANET regional training course on the conservation and use of 
germplasm of tropical fruits in Asia held at Indian Institute of Horticultural Research, 18-31 May 1997, Bangalore, India'. (Eds RK Arora, V Ramanatha Rao) pp. 235-245.

[22]. Tandon PL, Srivastava RP (1982) Note on new pests of mango in India. Science and Culture 48, 78-80.

[23]. Tenakanai D, Dori F, Kurika K (2006) Red-banded mango caterpillar, Deanolis sublimbalis Snellen (Lepidoptera: Pyralidae: Odontinae), in Papua New Guinea. In 'Pest and disease incursions: risks, threats and management in Papua New Guinea'. ACIAR Technical Reports No. 62 (Ed TV Price) pp. 161-165. (Australian Centre for International Agricultural Research: Canberra).

[24]. Verghese A, Jayanthi PDK (1999) Lepidopteran pest complex on mango inflorescence. Insect Environment 5, 51-52.

[25]. Verghese A, Nagaraju DK, Jayanthi PDK, Madhura HS (2005a) Association of mango stone weevil, Sternochetus mangiferae (Fabricius) (Coleoptera: Curculionidae) with fruit drop in mango. Crop Protection 24, 479-481.

[26]. Verghese A, Nagaraju DK, Vasudev V, Kamala Jayanthi PD, Madhura HS, Stonehouse JM (2005b) Effectiveness of insecticides of synthetic, plant and animal origin against the mango stone weevil, Sternochetus mangiferae (Fabricius) (Coleoptera: Curculionidae). Crop Protection 24, 633-636.

[27]. Waterhouse DF (1993) 'The major arthropod pests and weeds of agriculture in Southeast Asia'. (ACIAR: Canberra).

[28]. D.F. Waterhouse (ACIAR Consultant in Plant Protection).Biological Control of Insect Pest: Southeast Asian Prospects, Australian Centre for International Agricultural Research Canberra 1998.

[29]. Zaheruddeen SM, Sujatha A (1993) Record of Deanolis albizonalis (Hampson) (Pyralidae: Odontinae) as mango fruit borer in Andhra Pradesh. Journal of the Bombay Natural History Society 90, 528.

[30]. Zaman Z, Maiti B (1994) Insects and mite infesting seedlings of mango in West Bengal. Environment and Ecology 12, $734-736$. 